2. Ignatenko, Ye. (2011). Christmas Kontakion from Kallistrat's Greek Oktoechos: in search of the primary source. Scientific review of Ukrainian National Tchaikovsky academy of music: Early music - contemporary outlook. Kyiv, issue 102, book 5, pp. 79-99 [in Ukrainian].

3. Oktoechos of Kallistrat from the Moldavian Monastery in Dragomirna, 1769 (2005). Decoding of musical and verbal texts Ya. Mykhailuk, O. Tsalay-Yakymenko. Poltava-Kyiv-Lviv, 102 p. [in Ukrainian].

4. Stathis, G. (2002). Balasis. Orthodox Encyclopedia. Moscow. Vol. 4, pp. 284-285 [in Russian].

Russian].

5. Stathis, G., Nikitin, S. (2001). Antonios. Orthodox Encyclopedia. Moscow. Vol. 2, pp. $612-613$ [in

6. Haldaeakis, A. (2010). Joachim Salabasis. Orthodox Encyclopedia. Moscow. Vol. 23, pp. 188-189 [in Russian].

7. Tsalay-Yakymenko, O., Mykhailuk, Ya. (2003). Staff-notated Oktoechos from the Moldavian Monastery Dragomirna - Memorial of the Ukrainian-Moldavian musical connections. Musica humana. Vol. 1. Lviv, pp. 213-234 [in Ukrainian].

8. Yasynovs'kyi, Yu. (1996). Ukrainian and Belarusian staff-notated Heirmologia of the $16^{\text {th }}-18^{\text {th }}$ centuries. Catalogue and paleographical study. Lviv, 624 p. [in Ukrainian].

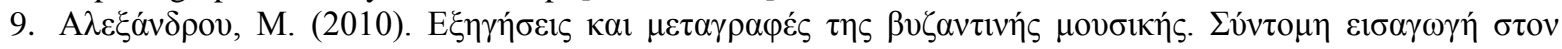

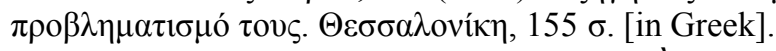

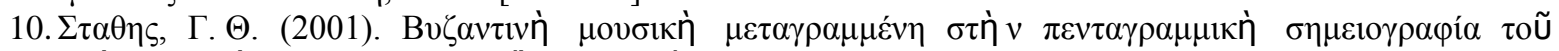

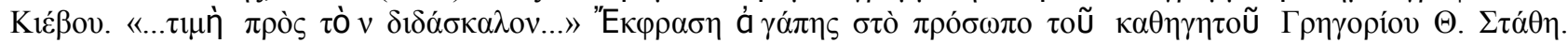

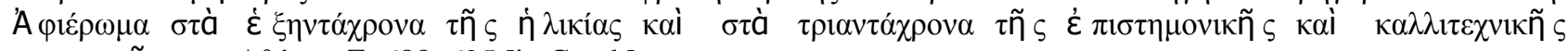

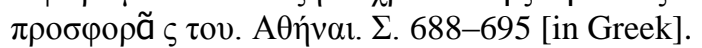

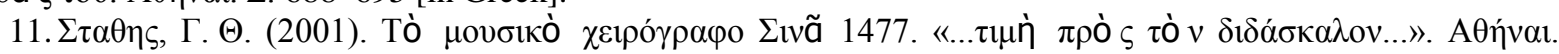
इ. 467-487 [in Greek].

Стаття надійшла до редакциї 25.01.2019 p.

УДК 785.11(477)

\author{
Гриценко Ольга Григорівна, \\ завідувач теоретичного відділу Маріупольської \\ спеціалізованої музичної школи, \\ здобувач Київського національного університету \\ культури і мистецтв \\ ORCID 0000-0001-9765-2379 \\ centremar2015@gmail.com
}

\title{
КОМПОЗИТОР ВАЛЕРІЙ АНТОНЮК: РИСИ СТИЛЮ
}

Мета: вивчення рис стилю сучасного київського композитора Valeriy Antonyuk у світлі його професійних здобутків, як митця XXI ст. Методологія: застосовано культурологічний підхід, системний аналіз та методи порівняльної стильової характеристики й слухової експертизи. Наукова новизна. Виявлено особливості стилю композитора В. Антонюка у світлі його пріоритетів в культурологічній, філософській, естетичній, онтологічній, психологічній та соціальній площинах через призму вивчення його професійних здобутків, як українського митця XXI ст. Висновки. Аналіз творчих здобутків сучасного українського композитора В. Антонюка засвідчує його спрямування до створення різножанрових музичних полотен. Визначено, що він послуговується надбаннями різних стильових доктрин, у його творчому методі можна знайти риси різних музичних напрямків, але всі вони - інструмент задля досягнення певної художньої цілі. В. Антонюк - митець, який відчуває себе невід'ємною, іманентною частиною буття в сенсі розвитку культурного процесу. Маючи світогляд людини XXI ст. з міцним, якісним підгрунтям музичної освіти, що містить у собі володіння широким спектром гуманітарних знань, він володіє й суто технічними інформаційними блоками сучасних засобів музичного програмування та сам озвучує свої нові симфонії й інструментальні твори. Він вдало експериментує та створює різножанрову музику, застосовуючи можливості практично всіх відомих композиторських технік. Дослідження творчого багажу В. Антонюка, - відомого українського митця, який, продовжуючи традиції української класичної музики, знаходиться в самому епіцентрі культурного простору XXI ст., - $є$ перспективою для подальших музикознавчих і культурологічних студій та сприятиме поєднанню окремих рис і деталей дослідницького процесу в цілісне полотно творчого портрета композитора в контексті його часу.

Ключові слова: композитор Валерій Антонюк, ліричний герой, митець, музичне програмування, симфонізм, стиль, творчість.

(C) Гриценко О. Г., 2019 
Гриценко Ольга Григорьевна, заведующая теоретическим отделением Мариупольской специализированной музыкальной школь, соискатель Киевского национального университета культуры и искусств

\section{Композитор Валерий Антонюк: черты стиля}

Цель: изучение черт стиля современного киевского композитора Валерия Антонюка в свете его профессиональных достижений, как художника XXI в. Методология: применены культурологический подход, системный анализ, методы сравнительной стилевой характеристикии и слуховой экспертизы. Научная новизна. Выявлены особенности стиля композитора В. Антонюка в свете его приоритетов в культурологической, философской, эстетической, онтологической, психологической и социальной плоскостях через призму изучения его профессиональных достижений, как украинского художника XXI в. Выводы. Анализ творческих достижений современного украинского композитора В. Антонюка свидетельствует его стремлении к созданию разножанровых музыкальных полотен. Установлено, что он пользуется достижениями различных стилевых доктрин, в его творческом методе можно найти черты разных музыкальных направлений, но все они - инструмент для достижения определенной художественной цели. В. Антонюк - художник, который чувствует себя неотъемлемой, имманентной частью бытия в смысле развития культурного процесса. Имея мировоззрение человека XXI в. с крепким, качественным базиссом музыкального образования, включающего в себя владение широким спектром гуманитарных знаний, он также обладает чисто техническими информационными блоками современных средств музыкального программирования и сам озвучивает свои новые симфонии и инструментальные произведения. Он удачно экспериментирует и создает разножанровую музыку, применяя возможности практически всех известных композиторских техник. Исследование творческого багажа В. Антонюка, - известного украинского художника, который, продолжая традиции украинской классической музыки, находится в самом эпицентре культурного пространства ХХ в., - является перспективой для дальнейших музыковедческих и культурологических исследований, способствуя объединению отдельных черт и деталей исследовательского процесса в целостное полотно творческого портрета композитора в контексте его времени.

Ключевые слова: композитор Валерий Антонюк, лирический герой, художник, музыкальное программирование, симфонизм, стиль, творчество.

Hrytsenko Olga, head of the theoretical Department of Mariupol specialized music secondary school, PhD student of Kyiv National University of Culture and Arts

Composer Valeriy Antonyuk: style features

Purpose of the article: study of stylistic features of modern Kyiv composer Valeriy Antonyuk in view of his professional achievements as an artist of the XXI century. Methodology: the cultural approach, system analysis and techniques of comparative description of style, audio expertise. Scientific novelty. The features of the style of composer V. Antonyuk in the light of his priorities in cultural, philosophical, aesthetic, ontological, psychological and social planes are revealed through the prism of studying his professional achievements as a Ukrainian artist of the XXI century. Conclusions. Analysis of musical developments of modern Ukrainian composer V. Antonyuk attests his focus on creation of pieces of music in different genres. It was determined that he uses gains of varied conceptions of style. Traits of different music trends may be found in his creative method. With that, they all serve as a tool to achieve a concrete creative goal. V. Antonyuk is an artist who feels himself inherent in objective reality, an immanent part of progressively evolutioning culture. With a worldview of a man of XXI century, having attained a high level in musical education, which included mastering a wide circle of humanities, he also comprehends essentially technical informational blocks of modern tools of musical programming and is capable of making a sound track to his new symphonies and instrumental pieces by himself. He is effective in experiments and composing the music of different genres, applying the options of almost all known composing techniques. Research of creative wealth of V. Antonyuk, a renowned Ukrainian artist, who, continuing the tradition of Ukrainian classical music, finds himself in the epicentre of cultural life of XXI century, - is the future of forthcoming musical and cultural studies. This research also will foster the introduction of specific features and facts from the research process into the integral canvas of the composer's creative portrait in the context of his time.

Key words: composer Valeriy Antonyuk, lyric hero, artist, music programming, symphony, style, creation.

Актуальність теми дослідження. Статтю присвячено визначенню рис стилю сучасного українського композитора Валерія Юрійовича Антонюка (1979 р.н.) та його творчого внеску в естетичний пласт музичної культури XXI ст. Значний доробок молодого митця складають понад 600 опусів, серед яких - десять симфоній, циклічні вокально-симфонічні, хорові та інструментальні твори, музика для кіно й реклами, авторська пісня та ін. ${ }^{1}$. Увага до його музики з боку виконавців, а також нотних і музичних видавців дають підстави стверджувати, що мистецький Олімп поповнився ще однією яскравою особистістю. Оскільки реагування з боку фундаментального мистецтвознавства на перебіг подій у царині творчих пошуків сучасних композиторів з метою виявлення нових знакових імен українських митців XXI ст. є дещо уповільненим, актуальність нашого дослідження - цілком очевидна. Ставимо за мету визначення рис стилю сучасного київського композитора Валерія Антонюка у світлі його професійних здобутків, як митця XXI ст. 
Аналіз досліджень і публікацій. Антологія мистецтвознавчих здобутків в царині теорії композиторського стилю поєднує в собі досягнення структуралізму, семіотики тощо та спонукає дослідників до з'ясування загальних рис вербальної та музичної мов. Акцентуація знакової природи музичного тексту від часів античних філософів Платона та Діогена Лаертського інтенсивно розробляється донині, в тому числі - українськими науковцями: О. Афоніною, Н. ГерасимовоюПерсидською, І. Коханик, І. Пясковським, Б. Сютою, С. Шипом $[1 ; 3 ; 6-7 ; 9 ; 11]$. Нами термін «стиль» буде застосовано 3 використанням традиційних меж парадигмального поля (як сукупності звичних термінів) в одному ряду 3 творчою манерою, почерком, письмом, артикуляцією тощо, найперше, як базової платформи, та з якісно новим змістом, що має підгрунтям діалектичну максиму єдності стиль $=$ метод.

В. Антонюк володіє не тільки різними техніками композиторського письма, а й методом написання електронної музики, - музичним програмуванням, про що розповів у своєму інтерв'ю [10]. Слід зазначити, що застосування дефініції «електронна музика» натепер має тенденцію до згортання. Естетична доктрина Е. Денисова щодо електронної музики, лише як музики, «...звукові об'єкти якої утворені електронними генераторами» дещо втрачає свою актуальність $[12,151]$. С.Шип знімає безапеляційність цього узагальнення та пропонує розшарувати поняття «електронна музика», відокремивши форму та зміст. Він конкретизує лише один, - прикладний аспект електронної музики, зазначаючи що «...матеріальною основою електронної музики є електронно вироблені, препаровані та синтезовані звуки» [11, 7-9]. В. Котонський надає більш повної характеристики концепту «електронна музика» та визнає, що «...3 одного боку, електронна музика пропонує новий спосіб комунікації композитора зі слухачем, а з іншого - вона не створила специфічних музичних рис, які б склали спільну платформу ії використання», відносячи до «спільної платформи» лише «...досягнення остаточного ефекту за допомогою електроакустичного обладнання» [2, 116]. Об’ємнішого визначення суті терміну «електронна музика» надають праці I. Ракунова, в яких пояснено термін «електронна музика» «у широкому сенсі, вміщуючи усі явища сучасної музики, пов'язані з вживанням штучно створених звучань, а також комп'ютера» $[8,14]$. Композитор А. Загайкевич включає в цей концепт «...увесь спектр жанрових різновидів музичної композиції, пов'язаних із використанням електронних засобів у музичній творчості, включно з електронним синтезом звуку та алгоритмічною композицією» $[4,51]$. Але загалом, комп'ютерна грамотність створює умови для зниження емоційного напруження від рецептивного очікування саме зовнішнього фактору електронної музики та спонукає композитора до безумовної зміни пріоритету на користь художнього контенту.

Вивчення параметрів стилю композитора Валерія Антонюка здійснюємо 3 урахуванням методологічної бази означених авторів, із розумінням нових ідей сучасного мистецтвознавчого дискурсу, при цьому пропонований нами культурологічний підхід демонструє альтернативні риси.

Виклад основного матеріалу. Отримавши свої перші уроки композиції, гармонії та контрапункту у В. Кирейка (учня Л. Ревуцького, - вихованця М. Лисенка), у НМАУ імені П.І.Чайковського В. Антонюк навчався у Г. Ляшенка, - учня А. Солтиса, який студіював композиторське мистецтво у свого батька М. Солтиса. Як спадкоємець магістральних національних композиторських шкіл, що ведуть генезу від М. Лисенка та М. Солтиса, В. Антонюк став продовжувачем традицій романтизму в українській музиці, плідно працює з великими симфонічними формами й активно освоює нові жанри. Стильова основа його композицій свідчить про засвоєння різних технічних засобів (неокласицизм, неоромантизм із елементами модернізму та мінімалізму, органічно поєднані з ритмікою рок-музики). Він пише зі слуху - без інструмента - відразу партитури, без знаків при ключі, однак його музика - тональна, бо в ній $є$ тяжіння до основних гармонічних центрів і яскраві оркестрові ефекти, завдяки максимальному використанню тембрової палітри інструментів. Він не застосовує прямих фольклорних цитат, однак для його музики властива національна природа українських образів-архетипів та їхня дотичність до подій сьогодення. Це $\epsilon$ показником того, що художнє тло, яке формує молодий український композитор, є відбитком освоєння його свідомістю складних, перш за все, - моральних колізій сучасного буття й відповідальності митця за нього.

Аналізуючи симфонічну творчість В. Антонюка, ми виявили закономірності, що дають можливість розглядати його симфонії як цілісне музичне полотно, єдине дискурсивне поле. Композитор створює свої симфонічні опуси як своєрідні драматургічні п’єси, - наративи, які не $є$ програмними, попри те, що мають назви (див. Прим.). Програмність композитор розуміє та реалізовує не як формування наочного ряду музичними засобами. Це більше нагадує створення певного фону, тла, своєрідного дискурсивного поля, що надає можливість кожному слухачеві 
скласти з запропонованих автором «пазлів» власну картину, зрозуміти процес народження образів, зазирнути в його творчу лабораторію, спробувати отримати ланцюжок асоціацій, - усвідомлених автором, або таких, що підсвідомо відбилися в його роботі. У своїх симфонічних творах композитор, застосовуючи звукову імітаційність (створення звукового ряду, що відтворює рух поїзду, хід годинника, вистріли, скандування гасел тощо), створюючи конкретні риси портретних чи сюжетних образів-архетипів, іде за ідеєю драматургічної логіки, демонструє справжню своєрідність та певний рівень узагальненості, завдяки чому кожен слухач може сформувати свій власний образний ряд, створити власний художній твір.

Говорячи про театральність у симфонічних опусах В. Антонюка, важко оминути прихильність композитора до спецефектів, - до створення жанровими, інтонаційними, метроритмічними засобами потрібної «картинки», необхідного образного портрету. Виразність гармонічних вертикалей тут важко переоцінити. Засобами музичної мови композитор досягає майже наочного відчуття того, що відбувається, використовуючи кінематографічний метод зіставлення. Візійні ряди його симфонічної музики мають риси типово національних образних концептів та $\epsilon$ проявом світоглядної пост-модернової позиції сучасного митця. Спільним для швидких частин симфоній В. Антонюка $\epsilon$ використання ритміки електро-гітарних ритмів із сучасного рок-стилю new metal (доручає це струнній та ударній групам оркестру). Крім нього, в симфонічній музиці цього ще ніхто не робить. В. Антонюк застосовує цей прийом у своїх CD-треках уже в чистому вигляді: new metal 3 оркестром, хором, солісткою сопрано та рок-гуртом (сам усе програмує, працюючи 3 відповідними семплами на комп'ютері). Окремо треба сказати про його специфічні акордові утворення. Композитор майстерно застосовує кластерну вертикаль, побудовану за принципом чергування малих та великих інтервалів на основі збільшеної терції. Для його музики характерне застосування накопичень хроматизмів у мелодико-інтонаційній лінії, а кластерні напластування гармоній «працюють» на розкриття драматургічного задуму та досягнення загальної художньої мети.

Безперечний мелодизм його композиторського обдарування завжди представлений свіжими мелодіями, лаконічними структурами і формами, які продовжують традиції К. Нельсона, С.Прокоф’єва О. Респігі, Я. Сибеліуса. Застосування ж В. Антонюком принципу монотематизму є вирішальним фактором для висновку про створення й функціонування його чотирьох перших симфоній як цілісного багаточастинного твору. Збереження конструктивної врівноваженості, створення тематичних побудов, що збалансовують романтичну, вільну від алгоритмічних структур форму, є найважливішою рисою композиторського почерку В. Антонюка, частиною його художнього мислення, його стильовим рішенням. Так, вивченння вокально-симфонічних кантат В. Антонюка для сопрано та симфонічного оркестру на слова О.Пушкіна, Ф.-Г. Лорки, В. Стуса, шляхом порівняльного аналізу авторської партитури та відомих виконавських редакцій, дозволяє стверджувати, що це - етапні твори для розвитку української камерно-симфонічної вокальної музики. Композиторські інтенції В. Антонюка, спрямовані на виявлення загальних емоційно-образних вібрацій, що утворюють систему алюзій також між іншими творами автора, формують єдине пасіонарне поле ліричного героя його музики, втіленому в жіночому виконанні у вокальносимфонічному жанрі. Вивчення музичного матеріалу й виконавських інтерпретацій його вокальносимфонічних кантат дозволило нам з'ясувати принципи циклізації як фундаментальної основи художнього мислення в сучасній українській музиці. У ході їх аналізу визначено, що прочитання вокальної партії Валентиною Антонюк у поєднанні з неординарними диригентськими рішеннями В. Шейка, М. Лисенка, Н.Пономарчук та В. Жадько вносить нові, несподівані нюанси в драматургічний план цих полотен. Мелодійне багатство й інтенсивне емоційне наповнення партитури В. Антонюка розкриваються щоразу по-новому; існування ж люфту для інтерпретаторської транскрипції свідчить про значний технічний та художній рівень композитора. Всі три вокально-симфонічні кантати, Симфонію № 2 «Фанфари» та Концерт для фортепіано та симфонічного оркестру В. Антонюка в авторському виконанні у супроводі Симфонічного оркестру Національної радіокомпанії України (диригенти - В. Жадько та В. Шейко, солістка - Валентина Антонюк) записано на фонди Українського радіо.

Самобутня природа авторського та виконавського стилю композитора й піаніста В. Антонюка репрезентує творчу діяльність митця на тлі загального стилю свого часу. Сповідуючи естетику романтизму, він не є прихильником фрагментарної композиції. Відчуття форми та ії̈ вдосконалення стильова особливість творчого письма цього сучасного композитора. Вражає його вміння лаконічно, у невеликий проміжок часу створити зміст, показати володіння композиторською технікою у двохтрьох періодах творів великих форм та у декількох фразах - в його інструментальних опусах: запропонувати «сюжет», означити його й надати розвитку. Саме це виділяє твори В. Антонюка та 
визначає художню майстерність митця-майстра. Складний синтаксис, емоційна насиченість, чітка прописаність деталей, конструктивна виваженість форми викликають запитання щодо стильового генезису творів В. Антонюка, - як у його світоспрямуванні, так і в плані суто композиторської техніки. Відповідь на ці питання криється у синтезі таланту й Школи, що $є$ фундаментом, базою, основою. Ліричний герой, якого творить В. Антонюк, від імені якого розмовляє з залом, надихає всіх оптимізмом світосприйняття, метафізичною вірою у найкраще, - це спроба зв'язати минуле й майбутнє, відродити небуття в новому житті, це відтворення досвіду у прийдешньому світі, - це і $\epsilon$ оновлена стильова парадигма, що $є$ втіленням українсько-польських композиторських традицій, розвинених у новому часі. Створивши власне метадискурсивне поле, він запропонував полілог часу та суспільству. Продовжуючи традиції від М.Лисенка, через сконцентровану пасіонарність Б.Лятошинського, екзистенційне світобачення В. Губаренка, М. Скорика, професійні пошуки В.Кирейка, Є. Станковича, В. Сильвестрова, інтонатику П. та Г. Майбороди, І.Шамо, В. Бібіка, I.Карабиця, Валерій Антонюк на сьогодні є уособленням сучасного мистецького середовища, його невід'ємною стильовою частиною. Доречним у цьому контексті навести вислів М. Скорика: «Я переконаний, що жоден видатніший український композитор не поминув усвідомлення свого зв'язку 3 національним корінням і впливу тисячолітньої традиції. Але це цілком не означає, що він має бути консервативним і поза «своїм подвір'ям» нічого не бачити. Навпаки, чим своєрідніше він його усвідомлює у творчості, чим різноманітніше поєднує з усіма сучасними світовими художніми тенденціями мистецького пошуку, не порушаючи при тім природності першоджерела, не боїться експериментувати, сміливо впроваджувати українські фольклорні елементи в модерні системи художнього мислення і здатний це зробити талановито й оригінально, тим більше він має право називатися національним митцем» [5, 70-71].

Як ми вже зазначали, творчий портфель композитора В. Антонюка нараховує багато різнохарактерних та різножанрових творів. Осмислення його творчого доробку не дозволяє зробити остаточних висновків щодо жанрової пріоритетності написаної ним музики, оскільки, володіючи цілим арсеналом композиторських технік, В. Антонюк працює в різних художніх напрямах та жанрах (крім театральних), висвітлює можливості багатьох музичних інструментів і людського голосу. Використовуючи увесь арсенал засобів музичної виразності, прийомів композиторської техніки, естетичні особливості художніх напрямів, течій та стилів, він сформував індивідуальну манеру авторського письма, яка має свій відбиток у творах різного обсягу, написаних для оркестрового, інструментального та вокального виконання. Серед них є також естрадні пісні, музика для кіно, музика для дітей тощо. Знаючи про юнацький досвід співпраці В. Антонюка - лідера рок-гурту «Літонапрокат» - з малими некласичними складами, стає зрозумілим застосування таких вертикалей, які, збагачуючи класичну гармонічну основу, привносять сонорові ефекти палітри рок-музики. Справедливо зазначимо, що саме відсутність надмірної кількості кластерних грон (іноді не завжди виправданих), відмова від брутального звукодобування, натомість - використання органічної та доцільної логіки розвитку ладотональної полісистеми, виразно характеризує яскраву індивідуальність В. Антонюка, - сучасного українського композитора, чия творчість на сьогодні $\epsilon$ одним 3 найвидатніших явищ національної культури.

В. Антонюк досить плідно працює в жанрі електронної музики, яку вірніше було б назвати просто музикою, яка пишеться із застосуванням електроніки. Отримавши перші уроки в Альма матер у В. Козліна, він самостійно опанував мистецтвом музичного програмування та створює в своїх композиціях звучання, максимально наближене до «живих» інструментів, майстерно передаючи навіть тонкощі виконавської агогіки та «дихання» симфонічного оркестру. Популярні в усьому світі альбоми В. Антонюка «Orchestral Drama», «Epic Strings», «Orchestral Action», «Symphonic Metal» були написані ним на замовлення музичної бібліотеки Manhattan Production Music. Альбоми «Comedy \& Cartoon-Comic Cavalcade», «Corporate-Fortune \& Fame», «Film Scores-Dangerous \& Deadly» - написані на замовлення музичної бібліотеки Sound Ideas/Westar Music. Диски з різножанровою продакшн музикою Валерія Антонюка ексклюзивно видають відомі музичні бібліотеки: Sonoton (Німеччина), Manhattan Production Music (США), Sound Ideas (Канада), Epitome Music (США), Roba Music (Німеччина), Fable Music (Австралія). Музика В. Антонюка, написана на замовлення цих музичних компаній (бібліотек), використовується на всесвітньо відомих телевізійних каналах, таких як АВС, CBS, NBC, BBC, «Відкритий канал» у кабельній ретрансляції програм телевізійної мережі, кабельній мережі, національною асоціацією кабельного телебачення.

Географічні межі творчості В. Антонюка визначені місцями написання, виконання та видання його музичних опусів (Україна, Австралія, Австрія, Грузія, Болгарія, Велика Британія, Італія, Канада, Німеччина, Польща, США, Японія). За рубежем широко виконується та видається його органна 
музика, що традиційно асоціюється в слухача зі світом доби, що відійшла в минуле. Але необароко все частіше має свій прояв у сучасному житті, тому інтерес до органної музики, як в Україні так і в цілому світі 3 кожним роком збільшується. Відомі твори В. Антонюка для органа соло - «12 тональних прелюдій» (2015), «Пасакалія ре-мінор» (2015), «Сцена» (2015), «Фантазія» (2015); «Молитва» (2015) стали значним внеском у всесвітній культурний пласт сучасної доби. Недаремно американське видавництво Lorenz 32015 р. видає ексклюзивно партитури творів В. Антонюка для органа соло «Petite Passacaglia», «Festive Voluntary», «An Ascension Canticle». У 2018 р. Японське видавництво Da Vinci Edition також розпочало видавати ексклюзивно органні партитури В. Антонюка «Passacaglia in D Minor», «Scene», «Fantasy», «Prayer», «12 Tonal Preludes».

Різножанрові симфонічні твори В. Антонюка неодноразово звучали на міжнародних фестивалях сучасної академічної музики «Контрасти», «Форум музики молодих», «Музичні Прем’єри Сезону», «Київ Музик Фест». Він співпрацює з відомими в Україні, та за ії межами симфонічними, хоровими, камерними колективами: Національним симфонічним оркестром України, Академічним симфонічним оркестром Національної філармонії України, Заслуженим академічним симфонічним оркестром Національної радіокомпанії України, Державним Академічним Естрадносимфонічним оркестром України, The Bulgarian Film Orchestra, Georgian Philharmonic Orchestra, струннимт квартетами «Collegium» та «Archi», Камерним хором «Кредо», Академічним камерним хором «Хрещатик», Національним ансамблем «Київські солісти», а також визнаними диригентами, солістами-інструменталістами й вокалістами.

В. Антонюк має професійні студійні записи своїх симфонічних і вокально-симфонічних творів, п'ять із яких увійшли до фондової скарбниці УР. Канадське видавництво Lighthouse Music Publications видає ексклюзивно партитури деяких його камерних творів із 2016 р. Видавництво Alea Publishing \& Recording (США) видає ексклюзивно партитури його творів для Бас-кларнета соло та різних складів кларнетів з 2016 р., а японське видавництво Da Vinci Edition, починаючи з 2017 р., видає ексклюзивно всі симфонії, інструментальні концерти, вокально-симфонічні, хорові, камерні, органні партитури, твори для дітей, а також CD-альбоми, - компакт-диски трансляційних записів симфоній і кантат (з 2018 р.).

Сучасний український митець В. Антонюк (композитор, аранжувальник, піаніст, мультиінструменталіст, рок-поп-співак, поет) вдало експериментує, багато пише та має щільний зв'язок із своєю аудиторією. Його музику виконують, сприймають, а творчість відзначено Премією Київського міського голови «За особливі досягнення молоді у розбудові столиці України» (2009), Премією імені Л. Ревуцького (за кантату «Чотири вірші для сопрано та симфонічного оркестру на слова В. Стуса»), (2010), Премією імені Б.Лятошинського (за Симфонію № 7 «Маскарад Непобачених Снів» (присвячується невинним жертвам воєн і терору), (2018). Він - лауреат міжнародного конкурсу ім. Сергія Прокоф’ єва «Україна-2000», має Гран-прі Міжнародного конкурсу «Солоспів (музика в кіно)» (2009), Золоту медаль (2010) та Міжнародну відзнаку в кіномистецтві «Дебют» (2011) Київського Міжнародного фестивалю документальних фільмів «Кінолітопис».

Наукова новизна. Виявлено особливості стилю композитора В. Антонюка у світлі його пріоритетів в культурологічній, філософській, естетичній, онтологічній, психологічній та соціальній площинах через призму вивчення його професійних здобутків, як українського митця XXI ст.

Висновки. Аналіз творчих здобутків сучасного українського композитора В. Антонюка засвідчує його спрямування до створення різножанрових музичних полотен. Визначено, що він послуговується надбаннями різних стильових доктрин, у його творчому методі можна знайти риси різних музичних напрямків, але всі вони - інструмент задля досягнення певної художньої цілі. В. Антонюк - митець, який відчуває себе невід'ємною, іманентною частиною буття в сенсі розвитку культурного процесу. Маючи світогляд людини XXI ст. 3 міцним, якісним підгрунтям музичної освіти, що містить у собі володіння широким спектром гуманітарних знань, він володіє й суто технічними інформаційними блоками сучасних засобів музичного програмування та сам озвучує свої нові симфонії й інструментальні твори. Він вдало експериментує та створює різножанрову музику, застосовуючи можливості практично всіх відомих композиторських технік. Дослідження творчого багажу В. Антонюка, - відомого українського митця, який, продовжуючи традиції української класичної музики, знаходиться в самому епіцентрі культурного простору XXI ст., - $\epsilon$ перспективою для подальших музикознавчих і культурологічних студій та сприятиме поєднанню окремих рис $\mathrm{i}$ деталей дослідницького процесу в цілісне полотно творчого портрета композитора в контексті його часу. 


\section{Примітки}

1. У доробку композитора В. Антонюка найпомітніші - «"Звучання Присутне" для симфонічного оркестру, десять симфоній (№ 1 «Гармонія Руху», 2011; № 2 «Фанфари», 2012; № 3 «Передбачувана Музика», 2013; № 4 «Система Бажань», 2014; № 5 «Про Війну», 2014; № 6 «Лемент Над Прірвою», 2014-2015; № 7 «Маскарад Непобачених Снів» (присвячується невинним жертвам воєн і терору), 2015-2016; № 8 «Театр Післязвуч», 2016-2017; № 9 «Сонячні Містерії», 2017, № 10 «Уособлення Іншого»); дві симфонічні поеми («"Омріяна Незбагненність" для струнного оркестру», 2015 і «Танці Часу, Що Минає», 2017). Циклічні хорові твори: «Истончается Тонкий Тлен», - кантата в шести частинах для змішаного хору на вірші О. Мандельштама (2001), «Сумні пейзажі» в п’яти частинах для змішаного хору на сл. П. Верлена в українському перекладі М. Лукаша (2001); Кантата в п’яти частинах для змішаного хору на вірші Т. Шевченка (2008); «Заповіт» на вірші Т. Шевченка для змішаного хору (2010); Частина Літургії («Алілуя», «Херувимська Пісня» та «Отче Наш») для змішаного хору (2012); «Вісім віршів Тараса Шевченка для змішаного хору» (2014); «Аве Марія» для змішаного хору (2015). Особливе місце належить жанру вокально-симфонічної кантати; цей доробок композитора представляють: «Кантата для сопрано та симфонічного оркестру на вірші Ф.-Г. Лорки» у перекладі М. Лукаша» (2005) та іiі 2-га редакція - мовою оригіналу (2011), «Чотири вірші для сопрано та симфонічного оркестру на вірші Василя Стуса» (2006) та «Кантата у чотирьох частинах для сопрано та симфонічного оркестру на вірші О. Пушкіна» (2007). Серед великих форм - Концерт для фортепіано та симфонічного оркестру (2007), Концерт для альта й симфонічного оркестру (2015-2017); Концерт для скрипки й симфонічного оркестру, (2015-2017); Концерт для кларнету й симфонічного оркестру (2017-2018); Концерт для віолончелі й симфонічного оркестру (2018). Повний перелік творів В. Антонюка та їхні записи містять Iнтернет-ресурси: URL: https://www.facebook.com/composerantonyuk/

URL: https://uk.wikipedia.org/wiki/Антонюк_Валерій_Юрійович

\section{Лimepamypa}

1. Афоніна О. С. Цитування як художній прийом «подвійного кодування» у музичному мистецтві постмодернізму. Актуальні проблеми історії, теорії та практики художньої культури : зб. наук. праць. Вип. XXXVI. Київ, 2016. 303 с. С. 161-172.

2. Бондаренко А. І. Електронна музика в європейському культурному просторі: аналіз концепцій. Мистецтвознавство України. Вип. 12. Київ, 2012. С. 113-118.

3. Герасимова-Персидская Н. А. Музыка. Время. Пространство / ред. Ирина Тукова. Київ : ДУХ і ЛІТЕРА, 2012. $408 \mathrm{c}$.

4. Загайкевич А. Л. Українська електронна музика: практика дослідження. Музика в інформаційному суспільстві: зб. наукових статей / упор. І. Б. Пясковський. Київ, 2008. С. 39-62.

5. Кияновська Л. О. Мирослав Скорик : людина і митець. Львів : Незалежний культурологічний журнал “ї”, 2008. 591 с.

6. Коханик И. Н. Динамика смыслообразования в музыкальном стиле. Науковий вісник НМАУ ім. П. I. Чайковського. Київ, 2006. Вип. 60. С. 25-32.

7. Пясковський I. Б. Оновлення романтичних і постромантичних традицій в ладогармонічному мисленні Б. Лятошинського. Українське музикознавство. Київ, 1991. Вип. 26. С. 74-93.

8. Ракунова І. М. Нові композиторські технології (на приакладі творчості Алли Загайкевич) : автореф. ... канд. мист.: 17.00.03. Київ, 2008. 16 с.

9. Сюта Б. О. Інтертекстуальність як засіб організації форми музичного твору в українській музиці постмодернізму. Науковий вісник Національної музичної академії України імені П. І. Чайковського : Українська та світова музична культура: сучасний погляд. Київ, 2005. Вип. 36, кн. 1. С. 20-32.

10. Шестеренко I. В. «Найголовніше - власний стиль» (ексклюзивне інтерв’ю з Валерієм Антонюком). Музика: електрон. верс. журн. № 3. Київ, 2015. URL: http://music.cultua.media/2816-valerij-antonyuknajholovnishe-dlya-mene-stvoryty-vlasnyj-styl/ (дата звернення: 22.12.2018).

11. Шип С. В. Про «техніцизм» в авангардистській музиці. Музика. Київ, 1979. № 3. С. 7-9.

12. Шульгин Д. Признание Эдисона Денисова: по материалам бесед. Москва : Композитор, 1998. 438 с. URL : http://dishulgin.narod.ru. (дата звернення: 25.02.2018).

\section{References}

1. Afonina O. S. (2016). Citing as an artistic method of «double coding» in the musical art of postmodernism. Actual problems of history, theory and practice of artistic culture: st. sciences. prat Vip XXXVI. Kyiv [in Ukrainian].

2. Bondarenko A. I. (2012). Electronic Music in the European cultural Space: analysis of conceptions. Art studies of Ukraine. Kyiv [in Ukrainian].

3. 3. Herasymova-Persydska N. A. (2012). Music. Time. Space / Ed. I. Tukova. Kyiv : SPIRIT AND LITERA [in Ukrainian].

4. Zagaikevich A. L. (2008). Ukrainian electronic music: research practice. Music in the Information Society: a collection of scientific articles / emphasis. I. B. Pyaskovsky. Kyiv [in Ukrainian].

5. Kiyanovska L. O. (2008). Miroslav Skorik: The Person and the Artist. Lviv : Independent cultural journal "Ï" [in Ukrainian]. 
6. Kokhanik I. N. (2006). Dynamics of meaning formation in a musical style. Scientific Herald National Music Academy of Ukraine named after P. I. Tchaikovsky. Vyp. 60. Kyiv [in Ukrainian].

7. Piaskovsky I. B. (1991). Updating romantic and post-romantic traditions in the harmonious thinking of B. Lyatoshinsky. Ukrainian music. Vyp. 26. Kyiv [in Ukrainian].

8. Rakunova I. M. (2008). The new composition technologies (using compositions of Alla Zahaykevych as examples). : authoref. dis. ... cand. must. : 17.00.03. Kyiv [in Ukrainian].

9. Syuta B. O. (2005). Intertextuality as a means of organizing the musical formes in the Ukrainian music in the postmodernism. Scientific Herald National Music Academy of Ukraine named after P. I. Tchaikovsky: Ukrainian and world music culture: modern look. Vyp. 36, Prince. 1. Kyiv [in Ukrainian].

10. Shesterenko I. V. "The most important thing is your own style" (an exclusive interview with Valery Antonyuk). Music: electronic vers. Journals. № 3. Kyiv. URL: http://music.cultua.media/2816-valerij-antonyuknajholovnishe-dlya-mene-stvoryty-vlasnyj-styl/ (due date: December 22, 2018) [in Ukrainian].

11. Ship S. V. (1979). About “technicalism” in avant-garde music. Music. № 3. Kyiv [in Ukrainian].

12. Shulgin D. (1998). Edison Denisov's Confession: based on interviews. Moskva : Composer. URL: http://dishulgin.narod.ru. (date of the beast: February 25, 2018) [in Russian].

Стаття надійшла до редакиії 01.02.2019 p.

УДК 78.092-027.543+792.78]:7-044.247(477:4)

\author{
Дружинець Маріанна Ігорівна, \\ викладач кафедри естрадного співу \\ Київської муніципальної академії естрадного \\ та циркового мистецтв, \\ здобувач Національної академії керівних кадрів \\ культури і мистецтв \\ ORCID 0000-0003-2843-8138 \\ marianna.druzhinec@gmail.com
}

\title{
ПІСЕННИЙ КОНКУРС ЄВРОБАЧЕННЯ ТА ВОКАЛЬНІ ТЕЛЕВІЗІЙНІ ТАЛАНТ- ШОУ ЯК ФАКТОР ЄВРОПЕЇЗАЦІЇ ТА ЄВРОІНТЕГРАЦІЇ УКРАЇНСЬКОЇ КУЛЬТУРИ
}

\begin{abstract}
Мета статті - розглянути основні тенденції і перспективи розвитку пісенного конкурсу Євробачення та вокальних талант-шоу «Х-Фактор», «Голос країни» в медіа-просторі України; розкрити їх специфіку та функціонування, визначити позитивні та негативні сторони, показати їх роль в європеїзації та євроінтеграції української культури. Методологія дослідження полягає в застосуванні компаративного, історико-логічного, аналітичного методів. Зазначений методологічний підхід дозволяє розкрити та піддати аналізу пісенний конкурс, вокальні талант-шоу, що транслювалися на українських каналах. Наукова новизна. Вперше у цій статті намагалися висвітлити специфіку та основні тенденції пісенного конкурсу Свробачення, телевізійних талант-шоу («Х-Фактор», «Голос країни»), розглянути їх як фактор європеїзації та євроінтеграції української культури. Проте недостатня розробленість в науці проблеми робить деякі положення дискусійними, розв'язання яких є важливим для сучасного культурного життя. Висновки. На українському екрані вже були представлені всі основні західні формати вокальних талант-шоу. До їх позитивних сторін можна віднести такі: втілення мрії в життя; спів «вживу»; професійна режисура та кращі представники вітчизняного шоу-бізнесу, а також зарубіжні фахівці; використання класичних творів світового та вітчизняного естрадного мистецтв, хітів 3 легендарних мюзиклів ХХ століття. Негативні сторони: відсутність довіри глядачів до чесності та об'єктивності організаторів при визначенні переможців. Шоу-проекти не є рівнозначними, відрізняються один від одного ступенем своєї креативності, багатством репертуарної палітри. Але спільними рисами вокального телешоу є те, що глядач знайомиться 3 реальними прикладами того, як завдяки поєднанню таланту, прагнення до самовдосконалення і напруженої праці збуваються мрії. Таким чином, поява в етері більшості популярних вітчизняних телеканалів вокальних талант-шоу, створених переважно на основі західних форматів, свідчить про високий ступінь європеїзації та євроінтеграції України у світову культуру масового зразка. Конкурс Свробачення дає можливість нашим артистам нести свою творчість в Свропу, у світ, тим самим інтегрувати українську культуру. Цей конкурс є стимулом для українських артистів, які, перш ніж виходити на світовий ринок у конкурсі Євробачення, - європеїзують свою творчість, роблять якісний європейський продук світового рівня, не втрачаючи при цьому кодовості української нації та культури.

Ключові слова: вокал, талант-шоу, європеїзація, євроінтеграція, пісенний конкурс Євробачення, «ХФактор», «Голос країни».
\end{abstract}

(C) Дружинець М. I., 2019 